\title{
Myopia/heavy eye syndrome
}

A rare cause of horizontal diplopia

Figure $1 \quad$ MRI of the orbits showed elongation and superolateral displacement of the globes (arrows)

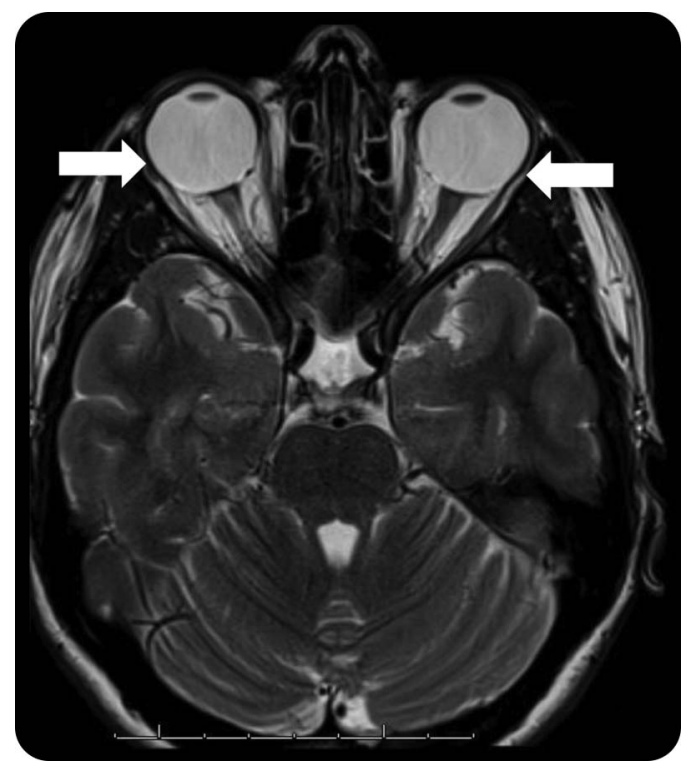

Figure 2 Stretching of the superior rectus-lateral rectus band (arrow) with inferior displacement of the lateral rectus muscles (horizontal lines), left greater than right

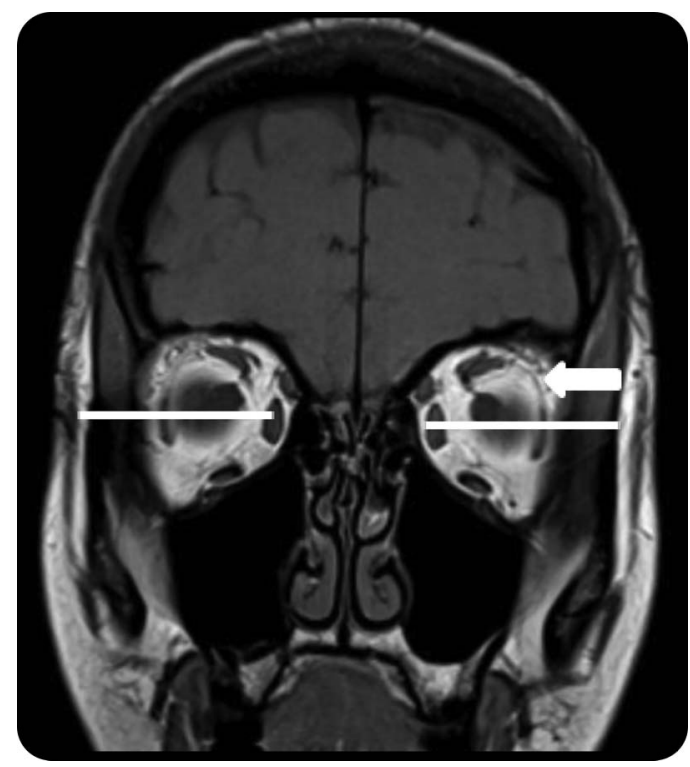

A 30-year-old woman with myopia ( -8 diopters) developed binocular horizontal diplopia over a year. She had chronic migraine and no other symptoms. Ocular motility showed a comitant esotropia (20 diopters), and 2diopter right hypertropia. MRI (figures 1 and 2) showed features of heavy eye syndrome, ${ }^{1}$ which is associated with superotemporal prolapse of the posterior globe, degeneration of lateral rectus-superior rectus band, and 
displacement of the lateral rectus downward. ${ }^{2}$ The abduction failure may be confused with a sixth nerve palsy. Our patient was treated with prisms with partial success, which along with strabismus correction are the treatment options.

Kannan M. Narayana, MD, Annette Nusbaum, MD, Steven L. Galetta, MD

From the Department of Neurology, Division of Neuro-ophthalmology (K.M.N., S.L.G.), and Department of Radiology (A.N.), NYU School of Medicine, New York.

Author contributions: K.M. Narayana: design and conceptualization of study, data collection, data analyses, interpretation of data, drafting and revising the manuscript. A. Nusbaum: data analyses, interpretation of data, drafting and revising the manuscript. S.L. Galetta: design and conceptualization of study, data analyses, interpretation of data, drafting and revising the manuscript.

Study funding: No targeted funding reported.

Disclosure: K. Narayana and A. Nusbaum report no disclosures relevant to the manuscript. S. Galetta has received consulting fees from Biogen and Genzyme. Go to Neurology.org for full disclosures.

Correspondence to Dr. Galetta: steven.galetta@nyumc.org

1. Demer JL, Von Noorden GK. High myopia as an unusual cause of restrictive motility disturbance. Surv Ophthalmol 1989;33: 281-284.

2. Krzizok TH, Schroeder BU. Measurement of recti eye muscles paths by magnetic resonance imaging in highly myopic and normal subjects. Invest Ophthalmol Vis Sci 1999;40:2554-2560.

\section{Share Your Artistic Expressions in Neurology 'Visions'}

AAN members are urged to submit medically or scientifically related artistic images, such as photographs, photomicrographs, and paintings, to the "Visions" section of Neurology ${ }^{\circledR}$. These images are creative in nature, rather than the medically instructive images published in the NeuroImages section. The image or series of up to six images may be black and white or color and must fit into one published journal page. Accompanying description should be 100 words or less; the title should be a maximum of 96 characters including spaces and punctuation.

Learn more at www.aan.com/view/Visions, or upload a Visions submission at submit.neurology.org.

\section{WriteClick ${ }^{\circledR}$ rapid online correspondence}

The editors encourage comments about recent articles through WriteClick:

Go to Neurology.org and click on the "WriteClick" tab at the top of the page. Responses will be posted within 72 hours of submission.

Before using WriteClick, remember the following:

- WriteClick is restricted to comments about studies published in Neurology within the last eight weeks

- Read previously posted comments; redundant comments will not be posted

- Your submission must be 200 words or less and have a maximum of five references; reference one must be the article on which you are commenting

- You can include a maximum of five authors (including yourself) 


\section{Neurology}

\section{Myopia/heavy eye syndrome: A rare cause of horizontal diplopia}

Kannan M. Narayana, Annette Nusbaum and Steven L. Galetta

Neurology 2015;85;737-738

DOI 10.1212/WNL.0000000000001872

\section{This information is current as of August 24, 2015}

\section{Updated Information \& Services}

References

Subspecialty Collections

Permissions \& Licensing

Reprints including high resolution figures, can be found at: http://n.neurology.org/content/85/8/737.full

This article cites 2 articles, 1 of which you can access for free at: http://n.neurology.org/content/85/8/737.full\#ref-list-1

This article, along with others on similar topics, appears in the following collection(s):

Diplopia (double vision)

http://n.neurology.org/cgi/collection/diplopia_double_vision MRI

http://n.neurology.org/cgi/collection/mri

Ocular motility

http://n.neurology.org/cgi/collection/ocular_motility

Information about reproducing this article in parts (figures,tables) or in its entirety can be found online at:

http://www.neurology.org/about/about_the_journal\#permissions

Information about ordering reprints can be found online:

http://n.neurology.org/subscribers/advertise

Neurology ${ }^{\circledR}$ is the official journal of the American Academy of Neurology. Published continuously since 1951, it is now a weekly with 48 issues per year. Copyright @ 2015 American Academy of Neurology. All rights reserved. Print ISSN: 0028-3878. Online ISSN: 1526-632X.

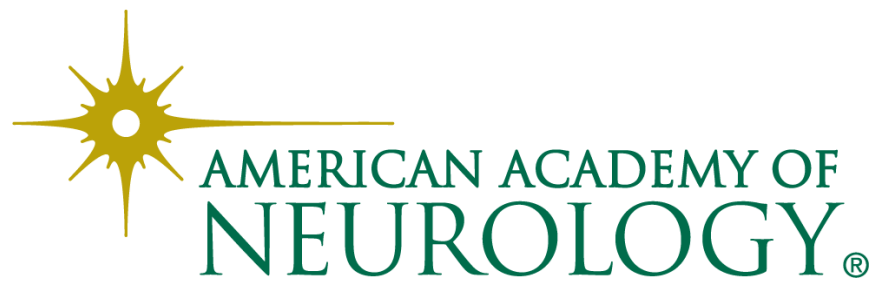

